\title{
Pengaruh Kerja Tim dan Pengembangan Karier terhadap Pengembangan Diri dan Keterlibatan Kerja Karyawan
}

\author{
Diah Pranitasari ${ }^{\left.1^{*}\right)}$, Abdul Rozaq ${ }^{2)}$ \\ ${ }^{1 *, 2)}$ Program Studi Manajemen, Sekolah Tinggi Ilmu Ekonomi Indonesia Jakarta \\ e-mail: diah_pranitasari@stei.ac.id ${ }^{1 *}$
}

\begin{abstract}
Research purpose is to determine the effect of team work and career development on self-development and work involvement of employees at the Jakarta BPJS Health headquarters.The population in this study were all employees of the BPJS Health headquarters office and the sample in this study was 100 employees. The analysis used is PLS-SEM through testing inner models, outer models and hypothesis testing using SmartPLS software.The results show that: first, team work influences work engagement; secondly, career development influences work involvement, and third, self-development influences work engagement. Practical implications, as a useful input for designing and implementing various strategic and practical steps for comforting and motivating employees in efforts to increase the level of employee involvement at the Jakarta BPJS Headquarters. Originality: The research constellation model with work involvement variables that are jointly analyzed with the variables of team work, career planning and self-development. Until now, there is still no research into work involvement using the composition of the three variables above and with data analysis techniques using SEM on Central Jakarta BPJS employees.
\end{abstract}

Keywords: Team Work, Career Development, Self- Development, Work Involvement

\section{PENDAHULUAN}

Keterlibatan kerja adalah ukuran seorang karyawan secara psikologis terhadap pekerjaannya dan memandang bahwa kinerja yang dilakukan sebagai ukuran harga diri. Keterlibatan kerja karyawan memiliki dampak besar bagi organisasi. Keterlibatan kerja yang tinggi dapat memberikan pengaruh kuat terhadap organisasi dan hal tersebut dapat berpengaruh pula pada keberhasilan organisasi dalam mencapai tujuan. Keterlibatan kerja karyawan diharapkan mampu memberikan dampak positif bagi organisasi dengan meningkatkan kinerja karyawan didalamnya (Robbins, 2019).

Upaya peningkatan keterlibatan kerja karyawan merupakan tugas besar bagi perusahaan, dan salah satunya adalah BPJS Kesehatan Jakarta. Pentingnya upaya untuk meningkatkan keterlibatan kerja ini didasarkan pada wawancara kepada Manajer HRD yang menunjukkan ada beberapa masalah umum yang masih dihadapi oleh perusahaan, yaitu karyawan yang belum terlibat penuh dalam setiap kegiatan perusahasan, adanya kepentingan untuk membentuk kerja tim yang solid, dan pengembangan karir yang tidak selalu ada tiap tahunnya.

Sejalan dengan fenomena di lapangan, penelitian dengan kajian keterikatan kerja telah dilakukan oleh beberapa peneliti, diantaranya Widyacahya dan Wulandari (2018) yang mengambil 
topik pengawasan dan kondisi kerja terhadap keterlibatan kerja, Joel dan Kairupan (2017) yang menggunakan gaya kepemimpinan transformal untuk memprediksi keterlibatan kerja karyawan dengan orientasi budaya individu sebagai variabel pemoderasi, Suwandana (2016) yang menempatkan self-efficacy sebagai prediktor keterlibatan kerja dan kepuasan kerja karyawan, Ariana dan Riana (2016) menguji hubungan work-family conflict, keterlibatan kerja dan stress kerja dengan kepuasan kerja karyawan, dan Sellar dan Andrew (2017) menggunakan kualitas kehidupan kerja (quality of work life) sebagai faktor yang mempengaruhi keterlibatan karyawan. Berdasarkan tinjauan riset sebelumnya, maka diketahui belum ada penelitian keterlibatan kerja dengan model konstelasi menggunakan variabel kerja tim, pengembangan karier dan pengembangan diri. Dengan demikian, studi ini dapat memberikan wawasan baru dalam menjelaskan determinan pengembangan diri dan keterlibatan kerja karyawan.

Penelitian ini bertujuan untuk mengetahui bagaimana pengaruh kerja tim, pengembangan karir dan pengembangan diri terhadap keterlibatan kerja sehingga dapat dijadikan sebagai informasi dan bahan masukan untuk merancang dan mengimplementasikan berbagai langkah strategis dan praktis bagi kenyamanan dan memotivasi karyawan dalam upaya peningkatan tingkat keterlibatan kerja karyawan di Kantor Pusat BPJS Kesehatan Jakarta.

\section{TINJAUAN PUSTAKA}

\section{Keterlibatan Kerja}

Keterlibatan kerja adalah memberikan kesempatan kepada karyawan untuk berpartisipasi memberikan dan menggunakan masukan-masukannya untuk peningkatan kinerja organisasi sehingga meningkatkan komitmen karyawan terhadap keberhasilan organisasi (Robbins and Judge, 2015). Hiriyappa (2009) menjelaskan keterlibatan kerja sebagai tingkat identifikasi dan keaktifan seorang pekerja dengan pekerjaannya dan keberhasilannya dalam melaksanakan pekerjaan adalah prestasi dirinya. Keterlibatan kerja merupakan suatu proses yang berlangsung di dalam kelompok, misalnya kelompok yang melibatkan para pekerja dan para pemimpin mereka atau kelompok lain yang lebih menekankan kepada perwakilan, proses tersebut dimana para karyawan sebagai individu diberi kebebasan yang lebih besar untuk membuat keputusannya sendiri.

Berdasarkan uraian di atas, dapat ditarik suatu kesimpulan bahwa keterlibatan kerja merupakan tingkat identifikasi, kepedulian dan tanggungjawab seorang karyawan terhadap pekerjaannya. Indikator keterlibatan kerja adalah respon untuk bekerja, perilaku melibatkan diri dalam pekerjaan, rasa bertanggung jawab terhadap pekerjaan, perasaan tentang pekerjaan yang belum terselesaikan dan absensi (Robbins and Judge, 2015).

\section{Kerja Tim}

Kerja tim didefinisikan sebagai kemampuan individu dalam berkolaborasi dan bekerja dengan orang lain untuk mencapai tujuan bersama dalam konteks kelompok atau tim (Lower, Newman, and 
Anderson-Butcher, 2017). Sebagai konstruksi umum, kerja tim melibatkan anggota kelompok atau tim yang bersedia berinteraksi tepat satu sama lain dengan menunjukkan berbagai keterampilan sosial dan proses kelompok seperti pemecahan masalah, negosiasi, pemberian umpan balik atau feed back, dan menggambarkan tanggung jawab dan akuntabilitas (Lower et al., 2017). Konsep kerja tim dan kemampuan untuk bekerja secara efektif dalam suatu kelompok atau tim adalah relevan dan penting untuk sukses dalam banyak konteks kehidupan seseorang (Baker dalam Lower et al., 2017).

Berdasarkan beberapa teori diatas dapat digarisbawahi bahwasannya hasil dari interaksi dalam kinerja antara individu sangat berpengaruh dengan individu yang lain. Dengan demikian kerja dalam tim atau kelompok sangat bisa menutupi kekurangan dari individu tertentu, yang artinya hasil dari kerja yang dilakukan oleh kelompok akan lebih efektif dan efisien. Indikator kerja tim adalah kerja sama, interaksi dan saling membantu (Pranitasari, 2019c).

\section{Pengembangan Karier}

Davis and Werther dalam Marwansyah (2010) menyatakan bahwa pengembangan karier (Career Development) adalah proses dan upaya pengembangan diri yang dijalani oleh seseorang untuk mewujudkan tujuan kariernya. Sudiro dalam Wahyuni (2014) menyatakan pengembangan karier adalah proses peningkatan kemampuan kerja individu yang dicapai dalam rangka mencapai karier yang diinginkan. Pengembangan karier adalah langkah-langkah yang dilakukan oleh seseorang atau oleh pimpinan sumber daya manusia dalam upaya pengembangan potensi karyawan untuk dapat dipromosikan menduduki jabatan yang lebih tinggi dalam upaya pencapaian tujuan perusahaan (Bahri, 2016).

Berdasarkan beberapa definisi diatas, maka dapat disimpulkan bahwa pengembangan karier adalah upaya pengembangan potensi seorang karyawan untuk dapat dipromosikan menduduki jabatan yang lebih tinggi sesuai dengan rencana kariernya. Indikator pengembangan karier adalah perlakuan yang adil dalam berkarir, keperdulian para atasan langsung, informasi tentang berbagai peluang promosi, adanya minat untuk dipromosikan dan tingkat kepuasan (Siagian, 2012).

\section{Pengembangan Diri}

Pengembangan diri merupakan kegiatan seseorang meningkatkan kesadaran dan identitas diri, mengembangkan potensi, meningkatkan kualitas hidup dan memberikan kontribusi dalam pekerjaannya sehingga dapat mewujudkan impian dan cita-citanya. Pengembangan diri dengan pendekatan psikologi, merupakan "pendekatan perilaku kognitif atau pemecahan masalah" (Aboalshamat, Hou, and Strodl, 2014). Definisi ini memperluas lingkup pengembangan diri menjadi spektrum terapi psikologis, sebagaimana yang dikemukakan oleh Farrand (2005) bahwa pengembangan diri merupakan pendekatan standar, disajikan dalam detail yang cukup untuk memungkinkan mereka untuk melakukan pengobatan diri sendiri atau dengan terapis dan pengembangan diri komersial maupun pengembangan diri seorang karyawan dalam organisasi. 
Pengembangan diri adalah tindakan yang dilakukan seseorang untuk meningkatkan kemampuan dan keterampilan dalam penyelesaian pekerjaan dan diikuti dengan peningkatan perilaku dalam lingkungan kerja saat ini maupun yang akan datang. Indikator yang digunakan: penilaian diri, kegiatan merefleksi diri, dan tindakan pengembangan diri (Pranitasari, 2019b).

\section{Hipotesis}

\section{Pengaruh Kerja Tim terhadap Pengembangan Diri}

Pekerjaan yang dilakukan dalam bentuk tim, akan lebih memotivasi karyawan untuk meningkatkan kemampuan dan keterampilannya. Sebagaimana yang dikemukakan oleh Pranitasari (2019a) yang menjelaskan kerja tim yang efektif akan meningkatkan motivasi karyawan untuk melakukan pengembangan diri. Manzoor, Ullah, Hussain, and Ahmad (2011) menyimpulkan bahwa kerja tim memiliki pengaruh positif terhadap kinerja karyawan. Hal ini dikarenakan dukungan dan dorongan rekan sekerja yang akan meningkatkan keinginan karyawan untuk selalu melakukan pengembangan diri. Ardana, Mujiati, dan Utama (2012) menjelaskan bahwa dengan kerja tim, semua anggota memiliki inisiatif untuk meningkatkan mutu melalui diskusi dan gugus kendali mutu, serta adanya persaingan dan perlombaan yang bersifat saling mendorong agar berprestasi. Hal tersebut mengindikasikan antar anggota tim terdapat kecenderungan untuk saling mendorong melakukan pengembangan diri. Ketika pengambilan keputusan tim, memainkan peran penting karena anggota tim harus berpartisipasi dalam proses pengambilan keputusan. Hal ini memberikan preferensi kepada anggota terampil dan kesempatan bagi karyawan untuk mengoptimalkan kemampuan mereka dan menghasilkan keputusan yang efektif (Sharma, Kansal, and Paliwal, 2012). Berdasarkan uraian tersebut, maka hipotesis yang diajukan adalah:

$\mathrm{H}_{1}$ : Kerja tim berpengaruh langsung positif terhadap pengembangan diri.

\section{Pengaruh Pengembangan Karier terhadap Pengembangan Diri}

Davis and Werther dalam Marwansyah (2010) menyatakan pendapat bahwa pengembangan karier (career development) adalah kegiatan pengembangan diri yang ditempuh oleh seseorang untuk mewujudkan rencana karier pribadinya. Setyabudi, Musadieq, dan Aziz (2018) pengembangan karier berpengaruh terhadap kinerja karyawan. Kinerja karyawan akan meningkat jika pengembangan karier yang ditingkatkan, hal ini menunjukkan bahwa kinerja karyawan dan pengembangan karier yang meningkat akan mendorong karyawan untuk pengembangan diri. Berdasarkan uraian tersebut, maka hipotesis yang diajukan adalah:

$\mathrm{H}_{2}$ : Pengembangan karier berpengaruh langsung positif terhadap pengembangan diri.

\section{Pengaruh Kerja Tim Terhadap Keterlibatan Kerja}

Kerja tim didefinisikan sebagai kemampuan untuk berkolaborasi dan bekerja dengan orang lain untuk mencapai tujuan bersama dalam konteks kelompok atau antar tim (Lower et al., 2017). Dengan adanya kerja tim didalam perusahaan, para karyawan dapat bekerja secara efektif dalam 
meningkatkan kinerjanya. Kerja tim menghasilkan sinergi positif melalui usaha yang terkoordinasi. Menurut Taroreh (2014), kinerja yang dicapai oleh sebuah tim akan menghasilkan kinerja yang lebih baik daripada kinerja perindividu di suatu organisasi ataupun suatu perusahaannya dan penelitiannya menunjukkan bahwa kerjasama tim memiliki pengaruh positif dan signifikan terhadap kinerja karyawan. Hal ini didorong dengan seiring meningkatnya kinerja perusahaan, didalamnya terdapat keterlibatan kerja yang tinggi. Berdasarkan uraian tersebut, maka hiposesis yang diajukan adalah:

$\mathrm{H}_{3}$ : kerja tim berpengaruh langsung positif terhadap keterlibatan kerja.

\section{Pengaruh Pengembangan Karier Terhadap Keterlibatan Kerja}

Pengembangan karier dapat dikatakan suatu kondisi yang menunjukkan adanya peningkatanpeningkatan status seseorang dalam organisasi dalam jalur karier yang ditetapkan dalam organisasi yang bersangkutan. Adapun salah satu faktor yang harus ditingkatkan adalah keterlibatan dalam suatu pekerjaan serta kedisiplinan dalam bekerja (Wansaga et al., 2016). Setiap karyawan memiliki tuntutan tersendiri di perusahaan untuk mengembangkan kariernya. Ketika sikap terhadap pengembangan karier karyawan tersebut cenderung positif, seperti memiliki prestasi yang baik, memiliki keterlibatan kerja yang tinggi, bekerja dengan professional, dikenal oleh pihak lain dan setia terhadap organisasi (Rizka, 2013). Berdasarkan uraian tersebut maka hipotesis yang dapat diajukan adalah:

$\mathrm{H}_{4}$ : Pengembangan karier berpengaruh langsung positif terhadap keterlibatan kerja.

\section{Pengaruh Pengembangan Diri Terhadap Keterlibatan Kerja}

Menurut Robbins and Judge (2015), keterlibatan kerja adalah tingkat sejauh mana seseorang memihak pekerjaannya, berpartisipasi secara aktif didalamnya dan menganggap pekerjaan tersebut penting bagi harga dirinya. Adanya keterlibatan kerja yang tinggi pada diri karyawan akan menyebabkan karyawan tersebut menjadi bersikap lebih positif dan mengurangi pikiran-pikiran negatif dalam diri karyawan (Caesens, 2017). Pengembangan diri memiliki efek positif dan signifikan langsung pada keterlibatan kerja. Semakin tinggi keinginan karyawan untuk mengembangkan diri akan meningkatkan keterlibatan kerja (Pranitasari, 2019b). Berdasarkan uraian tersebut maka hipotesis yang dapat diajukan adalah:

$\mathrm{H}_{5}$ : Pengembangan diri berpengaruh langsung positif terhadap keterlibatan kerja.

\section{METODE PENELITIAN}

\section{Desain Penelitian}

Penelitian ini merupakan penelitian asosiatif. Penelitian asosiatif merupakan penelitian yang bertujuan untuk mengetahui hubungan antara dua variabel atau lebih (Sugiyono, 2018). Peneliti memilih strategi asosiatif dengan tujuan untuk mengetahui pengaruh kerja tim, pengembangan karir terhadap pengembangan diri dan keterlibatan kerja karyawan BPJS Kesehatan. Metode penelitian yang digunakan adalah metode survei. Dimana penelitian survei ini menitikberatkan pada analisis kuantitatif. 


\section{Populasi dan Sampel}

Pada penelitian ini yang menjadi populasi adalah seluruh karyawan Kantor Pusat BPJS Kesehatan di Jakarta Pusat yang berjumlah 1400 karyawan periode Mei 2019 berdasarkan informasi dari Humas BPJS Kesehatan Jakarta.Teknik sampling menggunakan teknik purposive sampling yaitu karyawan yang sudah bekerja selama lebih dari satu tahun. Jumlah sampel yang diperoleh sebanyak sebanyak 100 responden dengan menggunakan pedoman SEM yang menggunakan rasio lima kali parameter (Hair et. al., 2014).

\section{Pengukuran Variabel}

Instrumen dalam penelitian ini menggunakan kuesioner, wawancara, dan riset pustaka. Kuesioner dalam penelitian ini diukur dengan skala likert, yaitu skala yang digunakan untuk mengukur sikap, pendapat, dan persepsi seseorang atau sekelompok orang tentang kejadian tertentu. Dalam skala likert digunakan skor (bobot nilai) yang diberikan terhadap jawaban yang telah disediakan, alternatif jawaban yang disediakan adalah:

1. Sangat setuju (diberi skor 4),

2. Setuju (diberi skor 3),

3. Tidak setuju (diberi skor 2),

4. Sangat tidak setuju (diberi skor 1).

Variabel pada penelitian ini adalah keterlibatan kerja karyawan (Y) dengan empat indikator penelitian, kerja tim $\left(\mathrm{X}_{1}\right)$ dengan tiga indikator penelitian, pengembangan karir $\left(\mathrm{X}_{2}\right)$ dengan lima indikator penelitian, dan pengembangan diri $(Z)$ dengan tiga indikator penelitian, dimana keempat akan dijadikan sebagai titik tolak ukur untuk menyusun item-item instrumen yang berupa pernyataan dalam sebuah kuesioner.

Indikator dan instrumen keterlibatan kerja diadaptasi dari Wibawa (2017); Widyacahya dan Wulandari (2018); serta Suwandana (2016). Indikator dan instrumen kerja tim diadaptasi dari Pranitasari (2019c) dan Lower et al., (2017). Indikator dan instrument pengembangan karier diadaptasi dari Bahri (2016); Marwansyah (2010); dan Wahyuni (2014). Indikator dan instrumen pengembangan diri diadaptasi dari Farrand (2005); dan Pranitasari (2019b).

\section{Tabel 1. Indikator Variabel Penelitian}

\begin{tabular}{ll}
\hline \multicolumn{1}{c}{ Variabel } & \multicolumn{1}{c}{ Indikator Penelitian } \\
\hline Keterlibatan Kerja (Y) & 1) Respon untuk bekerja. \\
& 2) Perilaku melibatkan diri dalam pekerjaan. \\
& 3) Rasa bertanggung jawab terhadap pekerjaan. \\
& 4) Perasaan tentang pekerjaan yang belum terselesaikan dan absensi. \\
\hline Kerja Tim $\left(\mathrm{X}_{1}\right)$ & 1) Kerja sama \\
& 2) Interaksi \\
& 3) Saling membantu \\
\hline
\end{tabular}




\begin{tabular}{ll}
\hline Pengembangan Karir $\left(\mathrm{X}_{2}\right)$ & 1) Perlakuan yang adil dalam berkarir. \\
& 2) Keperdulian para atasan langsung. \\
& 3) Informasi tentang berbagai peluang promosi. \\
& 4) Adanya minat untuk dipromosikan. \\
& 5) Tingkat kepuasan. \\
\hline Pengembangan Diri (Z) & 1) Penilaian diri \\
& 2) Kegiatan merefleksi diri \\
3) Tindakan pengembangan diri.
\end{tabular}

\section{HASIL DAN PEMBAHASAN}

\section{Analisis Data Hasil Penelitian}

Data hasil penelitian diolah dengan menggunakan SmartPLS 3.0 dengan gambar sebagai berikut berikut:

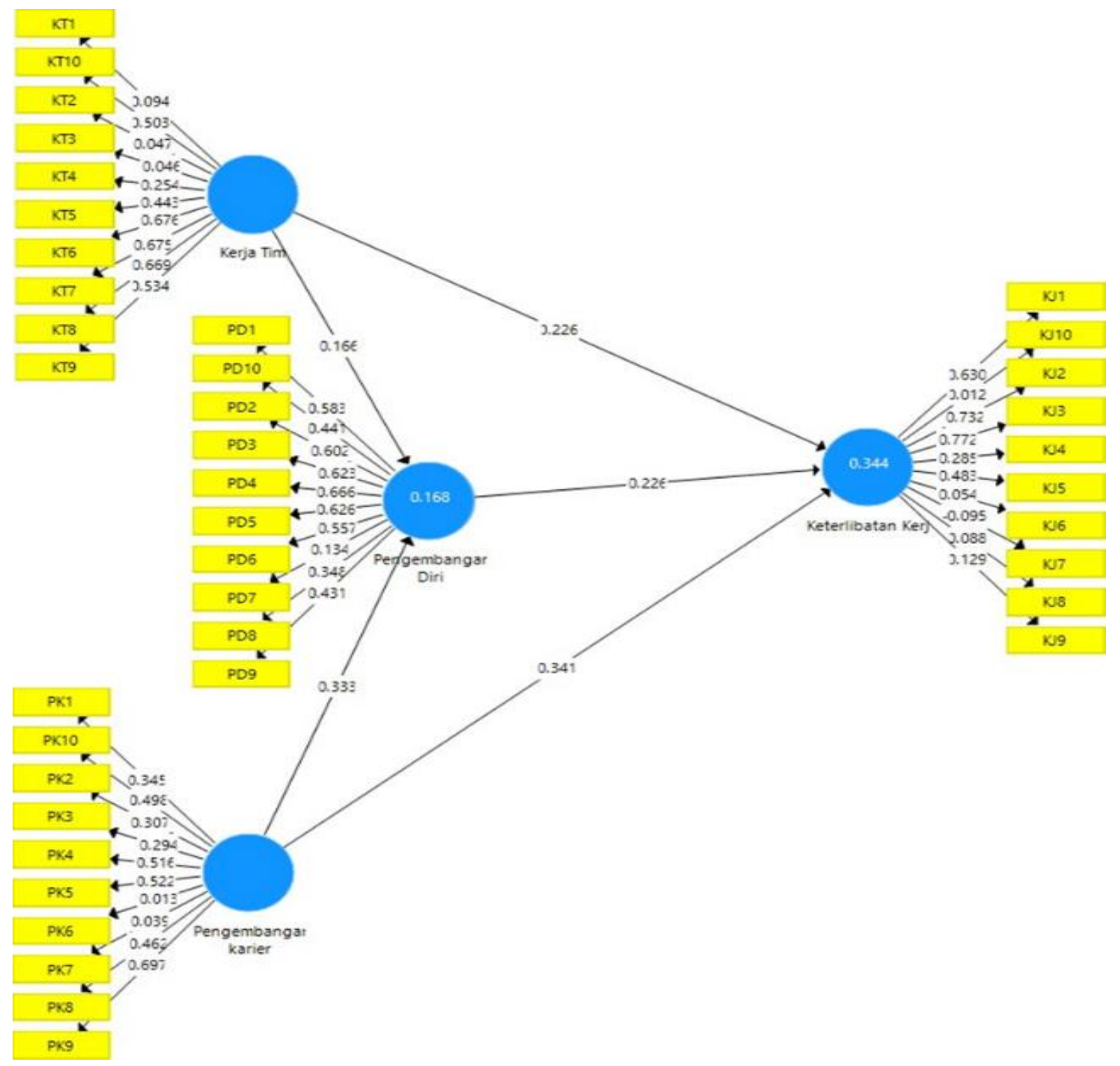

Gambar 1. Hasil Pengolahan Tahap I 
Tabel 2. Loading Factor Tahap I

\begin{tabular}{|c|c|c|c|c|}
\hline Variabel & Indikator & $\begin{array}{l}\text { Loading } \\
\text { Factor }\end{array}$ & Rule of Thumb & Kesimpulan \\
\hline \multirow[t]{10}{*}{ Kerja Tim } & KT 1 & 0,094 & 0,500 & Tidak Valid \\
\hline & KT 2 & 0,047 & 0,500 & Tidak Valid \\
\hline & KT 3 & 0,046 & 0,500 & Tidak Valid \\
\hline & KT 4 & 0,254 & 0,500 & Tidak Valid \\
\hline & KT 5 & 0,443 & 0,500 & Tidak Valid \\
\hline & KT 6 & 0,676 & 0,500 & Valid \\
\hline & KT 7 & 0,675 & 0,500 & Valid \\
\hline & KT 8 & 0,669 & 0,500 & Valid \\
\hline & KT 9 & 0,534 & 0,500 & Valid \\
\hline & KT 10 & 0,503 & 0,500 & Valid \\
\hline \multirow[t]{10}{*}{ Pengembangan karier } & PK 1 & 0,345 & 0,500 & Tidak Valid \\
\hline & PK 2 & 0,307 & 0,500 & Tidak Valid \\
\hline & PK 3 & 0,294 & 0,500 & Tidak Valid \\
\hline & PK 4 & 0,516 & 0,500 & Valid \\
\hline & PK 5 & 0,522 & 0,500 & Valid \\
\hline & PK 6 & 0,013 & 0,500 & Tidak Valid \\
\hline & PK 7 & 0,039 & 0,500 & Tidak Valid \\
\hline & PK 8 & 0,462 & 0,500 & Tidak Valid \\
\hline & PK 9 & 0,697 & 0,500 & Valid \\
\hline & PK 10 & 0,498 & 0,500 & Tidak Valid \\
\hline \multirow[t]{10}{*}{ Pengembangan Diri } & PD 1 & 0,583 & 0,500 & Valid \\
\hline & PD 2 & 0,602 & 0,500 & Valid \\
\hline & PD 3 & 0,623 & 0,500 & Valid \\
\hline & PD 4 & 0,666 & 0,500 & Valid \\
\hline & PD 5 & 0,626 & 0,500 & Valid \\
\hline & PD 6 & 0,557 & 0,500 & Valid \\
\hline & PD7 & 0,134 & 0,500 & Tidak Valid \\
\hline & PD 8 & 0,348 & 0,500 & Tidak Valid \\
\hline & PD 9 & 0,431 & 0,500 & Tidak Valid \\
\hline & PD 10 & 0,441 & 0,500 & Tidak Valid \\
\hline \multirow[t]{10}{*}{ Keterlibatan Kerja } & KJ 1 & 0,630 & 0,500 & Valid \\
\hline & KJ 2 & 0,732 & 0,500 & Valid \\
\hline & KJ 3 & 0,772 & 0,500 & Valid \\
\hline & $\mathrm{KJ} 4$ & 0,285 & 0,500 & Tidak Valid \\
\hline & KJ 5 & 0,483 & 0,500 & Tidak Valid \\
\hline & KJ 6 & 0,054 & 0,500 & Tidak Valid \\
\hline & KJ 7 & $-0,095$ & 0,500 & Tidak Valid \\
\hline & KJ 8 & 0,088 & 0,500 & Tidak Valid \\
\hline & KJ 9 & 0,129 & 0,500 & Tidak Valid \\
\hline & KJ 10 & 0,012 & 0,500 & Tidak Valid \\
\hline
\end{tabular}

Sumber: Data diolah, 2019

Convergent validity dari model pengukuran dapat dilihat dari korelasi antara skor item/ indikator dengan skor konstruknya (loading factor) dengan kriteria nilai loading dari setiap indikator > 0,5. Berdasarkan pengolahan data pertama dengan variabel kerja tim didapatkan 5 indikator yang tidak valid $(<0,5)$ yaitu KT 1, KT 2, KT 3, KT 4, KT 5 dan selebihnya valid $(>0,5)$. Variabel pengembangan karier didapatkan 7 indikator yang tidak valid $(<0,5)$ yaitu PK1, PK2, PK3, PK6, PK7, PK8, PK10 dan selebihnya valid $(>0,5)$. Variabel pengembangan diri didapatkan 4 indikator yang tidak valid $(<0,5)$ 
yaitu PD7, PD8, PD9, PD10 dan selebihnya valid (>0,5). Variabel keterlibatan kerja didapatkan 7 indikator yang tidak valid $(<0,5)$ yaitu $\mathrm{KJ} 4, \mathrm{KJ} 5, \mathrm{KJ} 6, \mathrm{KJ} 7, \mathrm{KJ} 8, \mathrm{KJ} 9, \mathrm{KJ} 10$ dan selebihnya valid $(>0,5)$. Sehingga nilai loading yang $<0,5$ harus dieliminasi atau dihapus dari model.

Pengolahan data tahap II diperoleh sebagai berikut:

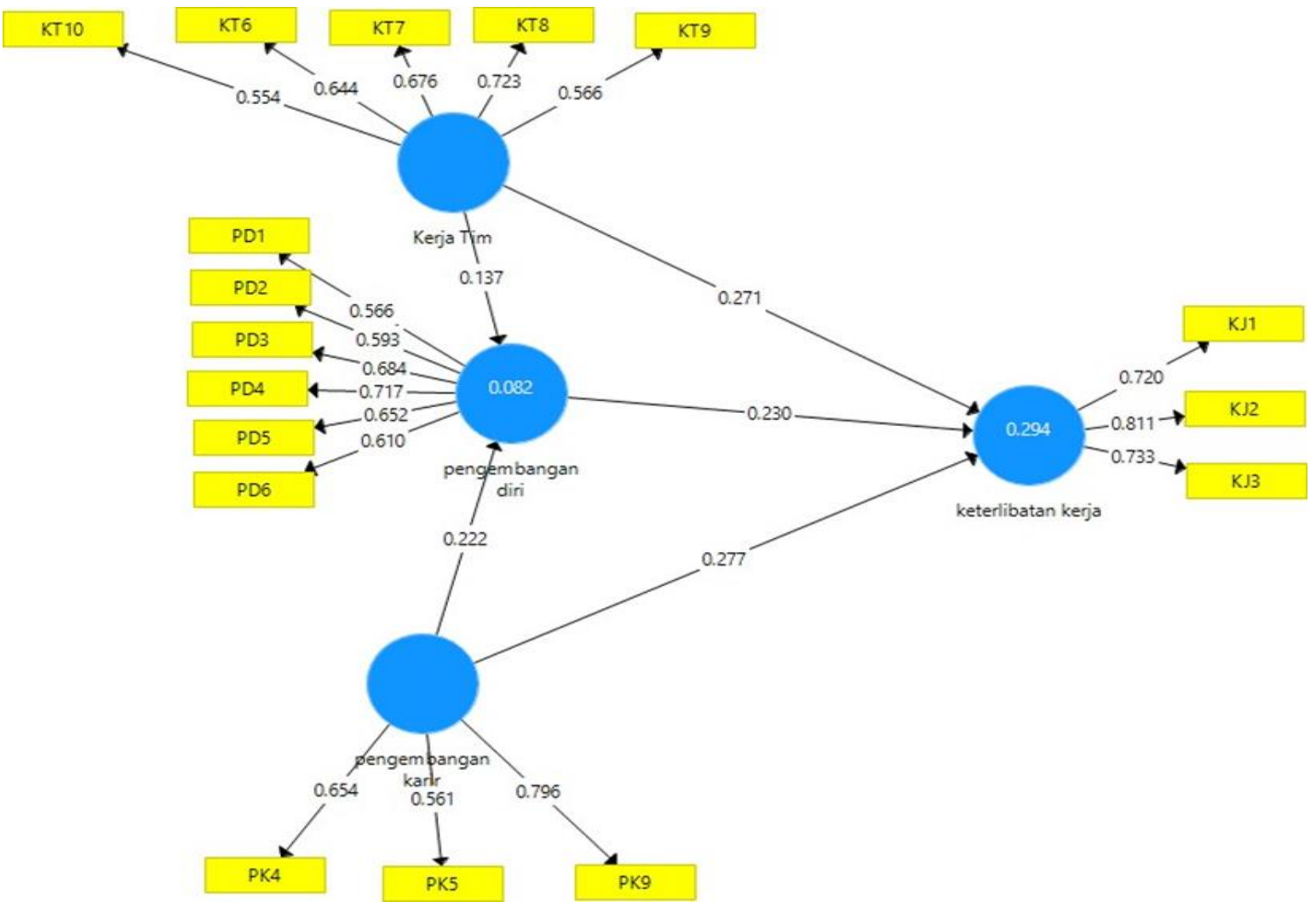

Gambar 2. Hasil Pengolahan Data Tahap II

Tabel 3. Loading Factor Tahap II

\begin{tabular}{llccc}
\hline \multicolumn{1}{c}{ Variabel } & \multicolumn{1}{c}{ Pernyataan } & $\begin{array}{c}\text { Loading } \\
\text { Factor }\end{array}$ & Rule of Thumb & Kesimpulan \\
\hline Kerja Tim $\left(\mathrm{X}_{1}\right)$ & KT 6 & 0,644 & 0,500 & Valid \\
& KT 7 & 0,676 & 0,500 & Valid \\
& KT 8 & 0,723 & 0,500 & Valid \\
& KT 9 & 0,566 & 0,500 & Valid \\
& KT 10 & 0,554 & 0,500 & Valid \\
\hline Pengembangan Karier $\left(\mathrm{X}_{2}\right)$ & PK 4 & 0,654 & 0,500 & Valid \\
& PK 5 & 0,561 & 0,500 & Valid \\
& PK 9 & 0,796 & 0,500 & Valid \\
\hline Pengembangan Diri $(\mathrm{Z})$ & PD1 & 0,566 & 0,500 & Valid \\
& PD2 & 0,593 & 0,500 & Valid \\
& PD3 & 0,684 & 0,500 & Valid \\
& PD4 & 0,717 & 0,500 & Valid \\
& PD5 & 0,652 & 0,500 & Valid \\
& PD6 & 0,610 & 0,500 & Valid \\
\hline Keterlibatan Kerja (Y) & KJ 1 & 0,720 & 0,500 & Valid \\
& KJ 2 & 0,811 & 0,500 & Valid \\
& KJ 3 & 0,733 & 0,500 & Valid \\
\hline
\end{tabular}

Sumber: Data diolah, 2019 
Berdasarkan Tabel 3 pada variabel kerja tim, nilai loading factor terbesar terdapat pada pernyataan KT 8 sebesar 0,723 yang berisi pernyataan "Anggota tim memberikan informasi yang akurat kepada rekan kerja". Pada variabel pengembangan karier, nilai loading terbesar terdapat pada pernyataan PK 9 sebesar 0,796 yang berisi pernyataan "Puas dengan sistem karir yang berlaku di perusahaan". Pada variabel pengembangan diri, nilai loading terbesar terdapat pada pernyataan PD 4 sebesar 0,717 yang berisi pernyataan "Mendiskusikan dengan rekan-rekan kerja untuk meningkatkan pencapaian hasil kerja". Dan pada variabel keterlibatan kerja, nilai loading terbesar terdapat pada KJ 2 sebesar 0,811 yang berisi pernyataan "Pekerjaan adalah bagian dari hidup".

Composite Reliabiliy $(C R)$ dari indikator yang mengukur konstruk CR digunakan untuk menampilkan reliabilitas yang baik. Suatu konstruk dinyatakan reliabel jika nilai composite reliability $>0,6$. Menurut Hair et al., (2014) koefisien composite reliability harus lebih besar dari 0,7 meskipun nilai 0,6 masih dapat diterima. Jika validitas konstruk telah terpenuhi, uji konsistensi internal tidak harus, hal ini dikarenakan konstruk yang valid sudah pasti reliabel, tetapi konstruk yang reliabel belum tentu valid (Cooper dan Schindler, 2014).

Tabel 4.Composite Reliability

\begin{tabular}{lccc}
\hline \multicolumn{1}{c}{ Variabel } & $\begin{array}{c}\text { Composite } \\
\text { Reliability }\end{array}$ & Rule of Thumb & Kesimpulan \\
\hline Kerja Tim & 0,771 & 0,6 & Reliabel \\
Pengembangan Karier & 0,713 & 0,6 & Reliabel \\
Pengembangan Diri & 0,804 & 0,6 & Reliabel \\
Keterlibatan Kerja & 0,799 & 0,6 & Reliabel \\
\hline
\end{tabular}

Sumber: Data diolah, 2019

Berdasarkan Tabel 4 bahwa hasil pengujian composite reliability menunjukkan nilai >0,6 yang berarti semua variabel dinyatakan reliabel.

\section{Uji Hipotesis}

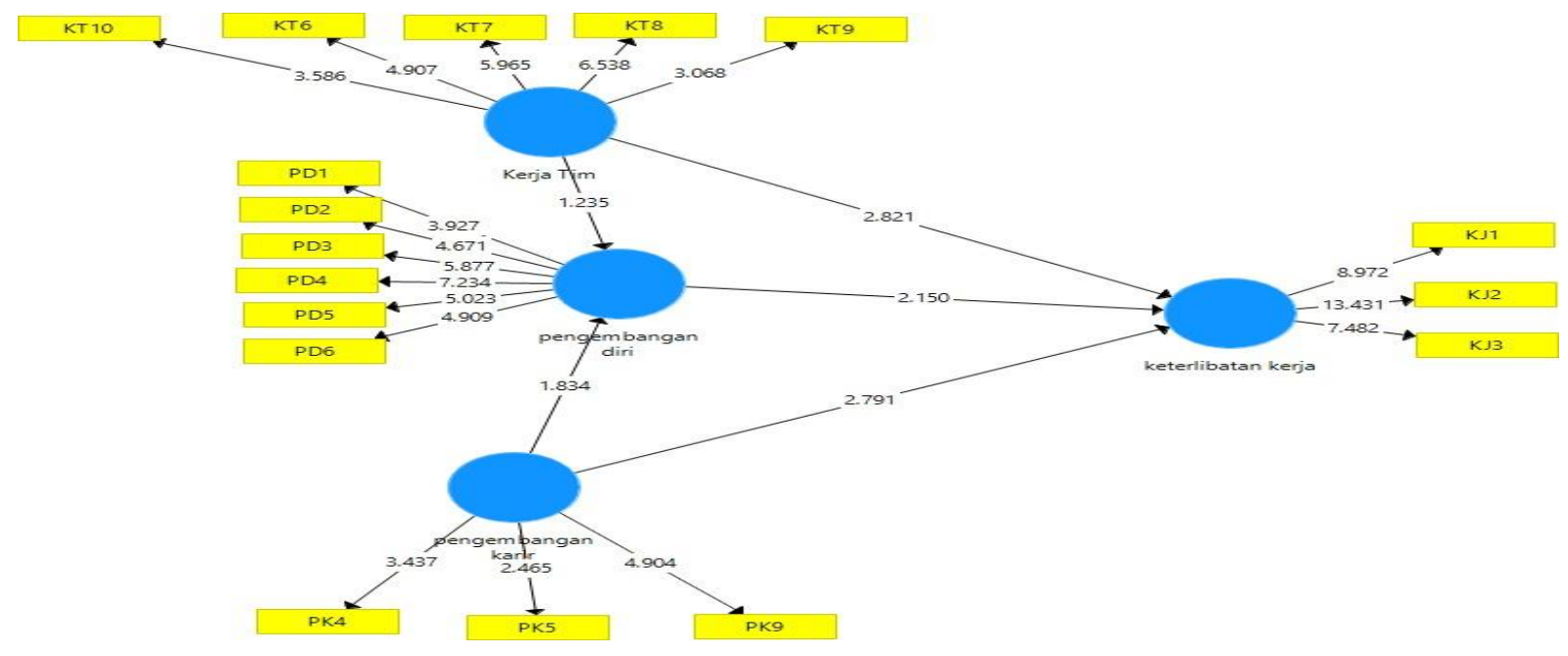

Gambar 3. Uji Hipotesis 
Tabel 5. Hasil Hipotesis Pengaruh Langsung

\begin{tabular}{|c|c|c|}
\hline & Hipotesis & Kesimpulan \\
\hline Hipotesis 1 & Terdapat pengaruh kerja tim terhadap pengembangan diri. & Ditolak \\
\hline Hipotesis 2 & $\begin{array}{l}\text { Terdapat pengaruh pengembangan karier terhadap } \\
\text { pengembangan diri. }\end{array}$ & Ditolak \\
\hline Hipotesis 3 & Terdapat pengaruh kerja tim terhadap keterlibatan kerja. & Diterima \\
\hline Hipotesis 4 & $\begin{array}{l}\text { Terdapat pengaruh pengembangan karier terhadap } \\
\text { keterlibatan kerja. }\end{array}$ & Diterima \\
\hline Hipotesis 5 & $\begin{array}{l}\text { Terdapat pengaruh pengembangan diri terhadap keterlibatan } \\
\text { kerja. }\end{array}$ & Diterima \\
\hline
\end{tabular}

Berdasarkan Tabel 5 dapat diketahui bahwa terdapat dua jalur yang tidak teruji signifikan yaitu kerja tim tidak berpengaruh terhadap pengembangan diri dan pengembangan karier tidak berpengaruh terhadap pengembangan diri.

Kerja tim tidak berpengaruh terhadap pengembangan diri. Hal ini bertolak belakang dengan pendapat yang dilakukan oleh Ardana et al., (2012) menjelaskan bahwa dengan kerja tim, semua anggota memiliki inisiatif untuk meningkatkan mutu melalui diskusi dan gugus kendali mutu, serta adanya persaingan dan perlombaan yang bersifat saling mendorong agar berprestasi. Penelitian ini juga bertentangan dengan penelitian Pranitasari (2019a) yang menyatakan kerja tim berpengaruh pengembangan diri. Berdasarkan wawancara yang dilakukan dengan salah seorang karyawan BPJS kesehatan, tidak semua karyawan terdorong untuk melakukan pengembangan diri dengan adanya kerja tim, beberapa karyawan justru terkadang mengandalkan salah seorang dari timnya, sehingga kerja tim dianggap kurang efektif.

Pengembangan karier tidak berpengaruh terhadap pengembangan diri. Hal ini bertolak belakang dengan pendapat Davis and Werther dalam Marwansyah (2010) bahwa pengembangan karir merupakan upaya seseorang untuk melakukan pengembangan diri. Hasil penelitian ini bertentangan dengan penelitian Setyabudi, Musadieq, dan Aziz (2018) yang menyimpulkan pengembangan karier berpengaruh terhadap motivasi pengembangan diri karyawan. Berdasarkan wawancara untuk mengetahui mengapa pengembangan karier tidak berpengaruh terhadap pengembangan diri pada karyawan BPJS kesehatan maka informasi yang didapat adalah beberapa karyawan tidak ingin menaikkan level kariernya dan lebih menyukai pekerjaannya sebagai staff biasa karena merasa takut memiliki tanggung jawab pekerjaan yang besar atas pekerjaan yang dicapainya tersebut dan juga gaji yang dianggap tidak sesuai dengan tanggung jawab pekerjaannya. Sehingga hal ini yang menyebabkan pengembangan karier tidak berpengaruh terhadap pengembangan diri.

Tabel 6. Hasil Uji Hipotesis Pengaruh Tidak Langsung

\begin{tabular}{|c|c|c|c|c|}
\hline & \multicolumn{2}{|c|}{ Direct } & \multicolumn{2}{|c|}{ Indirect } \\
\hline & Kerja Tim & P-Value & Kerja Tim & P-Value \\
\hline Keterlibatan & 2,821 & 0,005 & 0,917 & 0,359 \\
\hline & Pengembangan Karier & P-Value & Pengembangan Karier & P-Value \\
\hline $\begin{array}{l}\text { Keterlibatan } \\
\text { Kerja }\end{array}$ & 2,791 & 0,005 & 1,251 & 0,211 \\
\hline
\end{tabular}


Pada Tabel 6 menunjukkan bahwa pengembangan diri bukan merupakan variabel yang dapat memediasi variabel kerja tim maupun pengembangan karier terhadap keterlibatan kerja.

Untuk selanjutnya, jalur yang tidak signifikan dihilangkan dari model dan dilakukan pengolahan kembali, maka diperoleh koefisien jalur sebagai berikut:

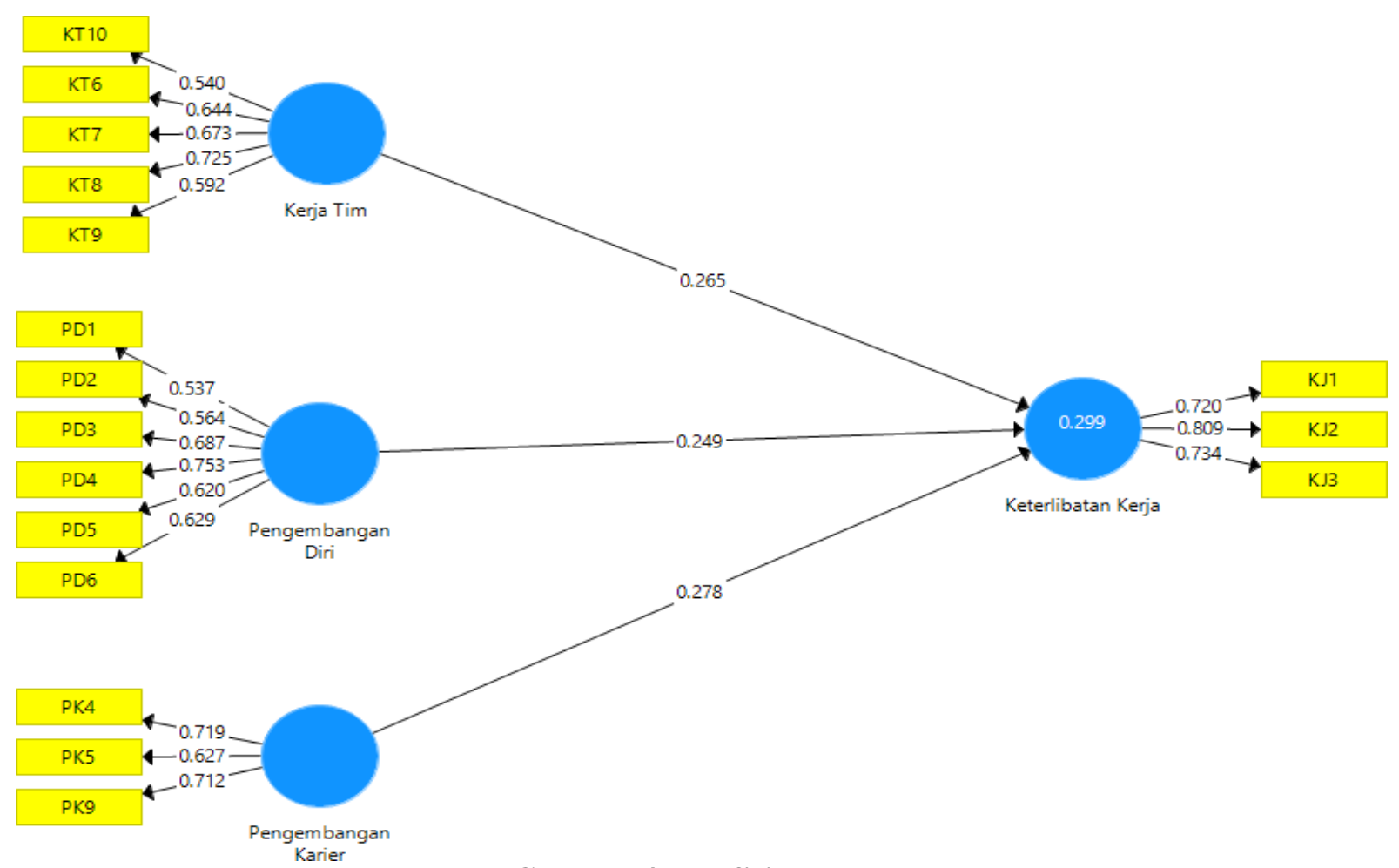

\section{Gambar 4. Koefisien Jalur}

Berdasarkan Gambar 4 pada variabel kerja tim memiliki pengaruh terhadap variabel keterlibatan kerja sebesar 0,265 atau 27\%. Pada variabel pengembangan karier memiliki pengaruh terhadap keterlibatan kerja sebesar 0,278 atau $28 \%$. Dan pada variabel pengembangan diri memiliki pengaruh terhadap keterlibatan kerja sebesar 0,249 atau $25 \%$.

\section{KESIMPULAN DAN SARAN}

Berdasarkan hasil penelitian dapat dinyatakan bahwa kerja tim, pengembangan karier dan pengembangan diri merupakan faktor penting untuk mendorong keterlibatan kerja karyawan. Penelitian ini telah membuktikan hubungan positif antara kerja tim dan keterlibatan kerja, pengembangan karier dan keterlibatan kerja serta pengembangan diri dan keterlibatan kerja, hal ini memberikan masukan yang bermanfaat bagi Kantor Pusat BPJS Kesehatan Jakarta untuk merancang dan mengimplementasikan berbagai langkah strategis dan praktis bagi kenyamanan dan memotivasi karyawan dalam upaya peningkatan tingkat keterlibatan kerja karyawan dan memberikan ruang lingkup yang luas untuk penelitian lebih lanjut.

Berdasarkan hasil penelitian maka dapat diberikan saran untuk meningkatkan keterlibatan kerja karyawan pada kantor pusat BPJS Kesehatan Jakarta, yaitu dapat melalui peningkatan kerja tim 
khususnya adanya kerjasama untuk saling memberikan informasi yang akurat antar anggota tim. Keterlibatan kerja juga dapat ditingkatkan melalui program pengembangan karier, yaitu dengan cara sosialisasi dan keterbukaan informasi sistem karier yang berlaku di perusahaan. Keterlibatan kerja juga dapat ditingkatkan melalui peningkatan motivasi karyawan untuk melakukan pengembangan diri dengan memfasilitasi forum diskusi antar karyawan untuk mendiskusikan permasalahan-permasalahan pekerjaan sehingga dapat mencapai hasil kerja yang optimal. Dan selain itu keterlibatan kerja karyawan dapat ditingkatkan dengan cara pimpinan selalu menanamkan pemahaman kepada setiap karyawan bahwa pekerjaan adalah bagian dari hidup karyawan.

\section{REFERENSI}

Aboalshamat, K., Hou, X.-Y., and Strodl, E. 2014. Self-Development, Self-Help, Human-Development, Coaching, Motivational Speaking, Psychological Well-Being; Self-Development, Self-Help, Human-Development, Coaching, Motivational Speaking, Psychological Well-Being. International Journal Of Psychology And Behavioral Sciences. Vol. 4 No. 4. Hal: 136-145.

Ardana, I. K., Mujiati, N. W., dan Utama, I. W. M. 2012. Manajemen Sumber Daya Manusia. Yogyakarta: Graha Ilmu.

Ariana, I. W. J., dan Riana, I. G. 2016. Stres Kerja terhadap Kepuasan Kerja Karyawan. Vol. 5 No. 7. Hal: 4630-4659.

Bahri, S. 2016. Pengaruh Pengembangan Karier dan Kompetensi terhadap Produktivitas Kerja serta Implikasinya pada Kinerja Pegawai Dinas PU Bina Marga Wilayah Kerja Sumatera Selatan. Journal Ecoment Global. Vol. 1 No. 1. Hal: 51-62.

Caesens, G. 2017. Perceived Organizational Support and Employees' Well-Being: The Mediating Role of Organizational Dehumanization. European Journal of Work And Organizational Psychology, Vol. 26 No. 4.

Farrand, P. 2005. Development of a Supported Self-Help Book Prescription Scheme In Primary Care. Primary Care Mental Health. Vol. 3 No. 1. Hal: 61-66.

Hair et. al. 2014. Partial Least Squares Structural Equation Modeling (PLS-SEM) an Emerging Tool in Business Research. European Business Review. Vol. 26 No. 2. Hal: 106-121.

Hiriyappa. 2009. Organizational Behavior. New Delhi: New Age International.

Lower, L. M., Newman, T. J., and Anderson-Butcher, D. 2017. Validity and Reliability of The Teamwork Scale For Youth. Research On Social Work Practice. Vol. 27 No. 6. Hal: 716-725.

Manzoor, S. R., Ullah, H., Hussain, M., and Ahmad, Z. M. 2011. Effect of Teamwork on Employee Performance. International Journal of Learning and Development. Vol. 1 No. 1. Hal: 110 126.

Marwansyah. 2010. Manajemen Sumber Daya Manusia (Kedua). Bandung: Alfabeta.

Pranitasari, D. 2019a. Keterikatan Kerja Dosen Sebagai Kunci Keberhasilan Perguruan Tinggi. Deepublish.

Pranitasari, D. 2019b. Key Success Factors of Lecturer's Work Engagement at College of Economics. Journal of Engineering and Applied Science. Vol. 4 No. 11. Hal: 3615-3619.

Rizka, Z. 2013. Sikap terhadap Pengembangan Karir dengan Burnout pada Karyawan. Jurnal Ilmiah Psikologi Terapan. Vol. 1 No. 2. Hal: 260-272.

Robbins. 2019. Manajemen Sumber Daya Manusia. Salemba Empat.

Robbins P, S., and Judge, T. A. 2015. Organizational Behavior. New Jersey: Robbins Stephen P. Dan Pearson Education, Inc.

Sharma, R., Kansal, M., and Paliwal, P. 2012. Effective and Efficient Team Work: Makes Things Happen. International of Social Sciences and Interdisiplinary Research. Vol. 1 No. 8. Hal: 154-171.

Siagian, S. P. 2012. Teori Motivasi dan Aplikasinya. Jakarta: Rineka Cipta.

Sugiyono. 2018. Metode Penelitian Kuantitatif. Jakarta: Alfabeta. 
Suwandana, I. G. M. 2016. Pengaruh Self-Efficacy terhadap Keterlibatan Kerja dan Kepuasan Kerja Karyawan pada Ibis Styles Bali Benoa Hotel. E-Jurnal Manajemen Unud. Vol. 5 No. 5. Hal: 3191-3218.

Taroreh, I. M. 2014. Analisa Pengaruh Motivasi Kerja, Pelatihan, Kepemimpinan, Komunikasi dan Kerjasama Tim terhadap Kinerja Para Suster Dina St.Yoseph di Indonesia. Jurnal Riset Bisnis dan Manajemen. Vol. 2 No. 4. Hal: 90-101.

Wahyuni, D. 2014. Karyawan (Studi pada Karyawan Tetap PT. Astra International, Tbk Daihatsu Malang). Jurnal Administrasi Bisnis (JAB). Vol. 8 No. 1. Hal: 1-10.

Wansaga, B., Oroh, S. G., Sendow, G. M., Manajemen, J., Ekonomi, F., dan Wansaga, J. 2016. Keterlibatan Kerja terhadap Kinerja Karyawan di PT. Angkasa Pura 1 (Persero) Manado. Jurnal Berkala Ilmiah Efisiensi. Vol. 16 No. 4. Hal: 1003-1014.

Wibawa, S. A. S. D. K. S. I. M. A. 2017. Dengan Pemediasi Komitmen Organisasional. E-Jurnal Ekonomi dan Bisnis Universitas Udayana. Vol. 8 No. 8. Hal: 3103-3132. 